\title{
PEMBINAAN KELOMPOK TANI OLEH PENYULUH PERTANIAN DI DESA BULALO KECAMATAN KWANDANG KABUPATEN GORONTALO UTARA
}

\author{
Irlan Karim \& Jusrin Kadir \\ STIA Bina Taruna Gorontalo \\ bukujurnalstia@binataruna.ac.id ${ }^{1} \&$ kadirjus04@gmail.com²
}

\begin{abstract}
ABSTRAK
Jenis penelitian yang digunakan dalam adalah jenis penelitian deskripsi dengan menggunakan sumber data yaitu observasi dan wawancara mendalam kepada sejumlah informan dan melakukan pencatatan data sekunder yang berkaitan dengan permasalahan penelitian. Adapun fokus penelitian adalah penyuluhan, pelatihan, dan pendampingan.

Berdasarkan hasil penelitian ditinjau dari segi penyuluhan, bahwa penyuluh pertanian kepada kelompok pertanian belum berjalan dengan baik dimana sering informasi tidak sampai kepada seluruh anggota kelompok tani tentang pembinaan yang akan dilakukan. Ditinjau dari pelatihan, bahwa pelatihan yang diberikan oleh penyuluh pertanian kepada kelompok tani belum efektif, dikarenakan tidak semua anggota kelompok tani mengikuti pelatihan dilakukan oleh penyuluh pertanian. Ditinjau dari segi pendampingan yang diberikan oleh penyuluh pertanian kepada kelompok tani belum efektif karena jumlah kelompok yang mendapatkan bantuan tersebut 9 kelompok sedangkan yang melakukan pendampingan hanya 1 orang.

Berdasarkan hasil simpulan tersebut, maka disarankan bahwa perlunya pihak penyuluh pertanian lebih meningkatkan penyuluhan terhadap kelompok tani agar tercapai sesuai harapan. Di harapkan penyuluh pertanian lebih meningkatkan pemberian pelatihan kepada kelompok tani bukan hanya sekali pelatihan harus di lakukan agar anggota petani lebih memahami apa yang di sampaiakan oleh penyuluh pertanian. Sedangkan pendampingan yang dimaksud yaitu pendampingan aggota kelompok terhadap penyuluh pertanian lebih di tingkatkan lagi.
\end{abstract}

Kata Kunci: Penyuluhan; Pelatihan; Pendampingan.

\section{PENDAHULUAN}

Indonesia terkenal sebagai
negara agraris dengan sektor kekayaan alam yang berlimpah, sumber daya alam dalam sektor pertanian, karena itu sebagian besar masyarakat Indonesia masih banyak yang bermata pencaharian atau bergantung hidup sebagai petani. Sektor pertanian sekarang ini masih menjadi sektor utama pembangunan nasional karena peranannya dalam penyediaan pangan, bahan baku hasil industri, pakan dan energi penyediaan lapangan kerja sampai 
PUBLIK: Jurnal Manajemen Sumber Daya Manusia, Administrasi dan Pelayanan Publik Sekolah Tinggi Ilmu Administrasi Bina Taruna Gorontalo Volume V Nomor 2 Desember 2018

sumber devisa, meskipun sumber pertanian selama ini dilakukan dengan maksimal namun masih ada saja hambatan-hambatan atau masalah-masalah terutama kaitannya dengan perubahan lingkungan atau iklim global yang semakin dinamis, menyadari hal tersebut, pemerintah telah mengeluarkan kebijakan untuk merevitalisasi penyuluhan, dan salah satu strategi dalam program tersebut adalah memberdayakan petani atau kelompok tani serta seluruh kekuatan yang dimiliki oleh petani dalam kelompoknya.

Penyuluhan

pertanian

merupakan pendidikan non formal bagi petani beserta keluarganya dimana kegiatan dalam ahli pengetahuan dan keterampilan dari penyuluh lapangan kepada petani dan keluarganya berlangsung melalui proses belajar mengajar.

Penyuluhan bisa menjadi sarana kebijakan yang efektif untuk mendorong pembangunan pertanian dalam situasi petani tidak mampu mencapai tujuannya karena keterbatasan pengetahuan dan wawasan. Sebagai sarana kebijakan hanya jika sejalan dengan kepentingan pemerintah atau organisasi yang mendanai jasa penyuluhan guna mencapai tujuan petani tersebut. Mereka juga diharapkan memainkan peranan baru, seperti memperkenalkan pertanian yang berkelanjutan yang menuntut keterampilan. Kebanyakan agen penyuluhan bernaung di bawah organisasi resmi seperti departemen (pemerintah), perguruan tinggi, atau perusahaan komersil lainnya.

Keberhasilan yang diperoleh dari struktur organisasi dan gaya kepemimpinan yang disepakati bersama ternyata sangat mempengaruhi efektivitas penyuluhan. Sistem latihan dan kunjungan yang dikembangkan dalam rangka meningkatkan efektivitas penyuluhan sebagai jembatan yang menghubungkan sumber informasi dengan petani untuk meningkatkan struktur latihan, cara penyampaian dan administrasi pelayanan penyuluhan.

Penyuluh pertanian yang berkompeten, di samping bisa berkomunikasi secara efektif dengan petani serta dapat mendorong minat belajar mereka. Para penyuluh pertanian harus berorientasi kepada masalah yang dihadapi petani, sesuai dengan kenyataan dan pemahaman mereka dan tidak hanya berorientasi kepada teknologi pertaniannya. Kegiatan penyuluhan banyak melibatkan pertimbangan nilai. Tidak jarang penyuluh dihadapkan pada keharusan memberi informasi tidak saja demi kepentingan petani sendiri tetapi juga untuk kepentingan masyarakatnya.

\section{Penyuluh}

diharapkan

mempunyai wawasan yang luas tentang dunia sekelilingnya sehingga dapat menafsirkan rangsangan dan pesan-pesan yang diterima. Penyuluh dapat membantu petani menganalisis situasi yang sedang berkembang agar mereka selalu siap untuk memberikan solusi kepada petani secara "tepat waktu" mengenai halhal yang tidak diinginkan yang mungkin terjadi atas beberapa aspek permasalahan, petani akan mampu memecahkan masalahnya, bahkan kadang-kadang cukup dengan hanya penjelasan masalah denga analisis yang sistematis. Penyuluh seharusnya menganalisis terlebih 
dahulu permasalahan yang dihadapi petani sebelum memutuskan untuk membantunya.

Sering petani memutuskan sesuatu berdasarkan pada kepentingannya sendiri, tetapi ada saat-saat dimana penyuluh perlu mengambil keputusan demi kepentingan petani. Dalam menghadapi masalah yang rumit, mungkin petani memerlukan bantuan dari luar seperti yang diberikan oleh agen penyuluhan. Namun, bila masalahnya cukup sederhana petani dapat menyelesaikannya sendiri, meskipun petani mungkin mau menerima bantuan dengan senang hati. Dalam hal ini, penyuluh menjalankan tugasnya lebih kearah pelayanan dibandingkan pendidikan.

Lembaga penyuluhan memegang peranan penting dalam membimbing petani mengorganisasikan diri secara efektif. Untuk meningkatkan efektivitas sistem kerja latihan dan kunjungan dari kegiatan penyuluhan guna menumbuhkan peran serta petani dalam pembangunan pertanian, maka dilakukanlah pembinaan kepada kelompokkelompok tani yang telah terbentuk secara rutin agar nantinya kelompok tani mampu berkembang menjadi kekuatan ekonomi yang memadai dan selanjutnya akan mampu menopang kesejahteraan anggotanya.

Oleh sebab itu sebagai ujung tombak keberhasilan pembangunan pertanian adalah petani. Peran serta masyarakat di pedesaan yang umumnya memiliki mata pencaharian sebagai petani sangat trategis dan menunjang keberhasilan pembangunan pertanian. Oleh karena itu pengetahuan dan keterampilan petani harus terus ditingkatkan sehingga para petani dalam pengelolaan sektor pertanian menjadi lebih baik, sehingga sangat dibutuhkan peran pemerintah untuk meningkatkan pengetahuan kepada mereka mengenai pengelolaan pertanian dengan baik sehingga memerlukan penyuluh untuk melakukan sosialisasi kepada para petani. Pemerintah harus memberikan bantuan fasilitas yang dibutuhkan para petani sehingga petani mendapatkan kemudahan dalam mengembangkan sektor pertanian

Pembinaan kelompok tani oleh penyuluh pertanian yang ada di Desa Bulalo Kecamatan Kwandang Kabupaten Gorontalo Utara, sebelum mulai penanaman padi seharus ada tim dari penyuluh yang harus memberikan pelatihan atau sosialisasi kepada petani baik bagaimana cara merawat dan memberikan pupuk dan obat-obatan sesuai takaran yang ditentukan.

Pembinaan kelompok tani oleh penyuluh Pertanian di Desa Bulalo Kecamatan Kwandang Kabupaten Gorontalo Utara yaitu pembinaan peningkatan semangat kerja terhadap anggota kelompok tani. Pembinaan ini. bertujuan agar anggota kelompok tani lebih memahami bagaimana cara meningkatkan semangat kerja yang lebih baik. Kemudian pembinaan sikap keterbukaan kelompok tani. Pembinaan ini bertujuan agar ketua dan anggota kelompok tani saling terbuka. Dan di desa Bulalo memiliki 9 kelompok tani yang masing-masing kelompok tani mempunyai Anggota berbeda-beda.

Pembinaan kelompok tani telah dilakukan melalui penyuluh atau 
PUBLIK: Jurnal Manajemen Sumber Daya Manusia, Administrasi dan Pelayanan Publik

Sekolah Tinggi Ilmu Administrasi Bina Taruna Gorontalo Volume V Nomor 2 Desember 2018

sosialisasi diikuti oleh para petani, Namun kenyataannya belum maksimal dilakukan, disebabkan partisipasi masyarakat terutama yang tergabung dalam kelompok tani petani masih kurang yang hadir sehingga penyuluhan tidak berjalan dengan baik disebabkan oleh anggota yang tidak hadir.

Bentuk pembinaan lain dilakukan melalui pelatihan kelompok tani di Desa Bulalo telah dilakukan, namun kenyataannya belum maksimal pelatihan lebih banyak teori dan sangat kurang pemberian materi dalam bentuk praktek. contohnya pelatihan cara menanam dengan baik dan cara memberikan pupuk yang baik dan benar hal tersebut kurang dilakukan.

Pembinaan juga dilakukan dalam bentuk pendampingan kelompok tani namun kenyataannya masih belum optimal, para petani hanya dibiarkan begitu saja tidak melakukan pendampingan lanjutan dari penyuluh pertanian, padahal para petani sangat membutuhkan pendampingan bagaimana memelihara tanaman sehingga mereka tidak banyak mengalami kegagalan panen.

\section{PERMASALAHAN}

Berdasarkan uraian tersebut maka rumusan masalah penelitian ini adalah: Bagaimana Pembinaan Kelompok Tani Oleh Penyuluh Pertanian di Desa Bulalo Kecamatan Kwandang Kabupaten Gorontalo Utara?

\section{TUJUAN PENELITIAN DAN MANFAAT PENELITIAN}

\section{Tujuan Penelitian}

Dalam penelitian ini, tujuan yang ingin dicapai adalah untuk mengetahui tentang Pembinaan Kelompok Tani Oleh Penyuluh Pertanian di Desa Bulalo Kecamatan Kwandang Kabupaten Gorontalo Utara.

\section{Manfaat Penelitian}

Manfaat yang dapat diambil dari penelitian ini adalah sebagai berikut:

1. Manfaat teoritis yaitu penelitian ini diharapkan kiranya dapat dijadikan sebagai bahan informasi yang berharga dalam pengembangan ilmu pengetahuan, terutama yang berkaitan dengan pembinaan kelompok tani oleh penyuluh pertanian di Desa Bulalo Kecamatan Kwandang Kabupaten Gorontalo Utara dan menjadi bahan bacaan serta sebagai bahan pertimbangan untuk mengkaji masalah yang sama bagi penelitian berikutnya dimasa yang akan datang.

2. Manfaat praktis yaitu diharapkan kiranya dapat dijadikan sebagai bahan informasi, alternatif sebagai pemecahaan masalah yang berkaitan dengan pembinaan kelompok tani oleh penyuluh pertanian di Desa Bulalo Kecamatan Kwandang Kabupaten Gorontalo Utara.

\section{METODE PENELITIAN}

Metode yang digunakan dalam penelitian mengenai pembinaan kelompok tani oleh penyuluhan 
pertanian yang ada di Desa Bulalo Kecamatan Kwandang Kabupaten Gorontalo Utara, adalah metode deskriptif dengan pendekatan kualitatif. Menurut Bogdan dan Taylor (Moleong, 2008: 3) metologi kualitatif sebagai prosedur penelitian yang menghasilakan data deskriptif berupa kata-kata tertulis atau lisan dari orang-orang dari perilaku yang diamati.

Adapun yang menjadi sumber dalam penelitian adalah data primer dan data sekunder. Untuk memperoleh data dan informasi yang diperlukan dalam penelitian ini maka teknik yang digunakan pada penelitian adalah observasi, wawancara dan dokumentasi.

Sedangkan teknik analisis kualitatif dilakukan melalui beberapa tahapan pemrosesan satuan, kategorisasi termaksud pemeriksaan keabsahan data, diakhiri dengan penafsiran data dengan kata-kata.

\section{Fokus Penelitian}

Adapun fokus penelitian dalam membahas tentang pembinaan kelompok tani oleh penyuluh pertanian di Desa Bulalo Kecamatan Kwandang Kabupaten Gorontalo Utara adalah pada penyuluhan, pelatihan, dan pendampingan, yang dapat dijelaskan sebagai berikut:.

\section{Penyuluhan}

Penyuluhan yang dimaksud dalam penelitian ini adalah dimana para penyuluh pertanian menyampaikan berbagai informasi kepada seluruh ketua kelompok tani yang kemudian akan meneruskan informasi yang didapat kepada para anggota petani.

\section{Pelatihan}

Pelatihan yang dimaksud dalam penelitian ini dimana para penyuluh memberikan pelatihan kepada para ketua kelompok tani yang akan meneruskan kepada para anggota tani lainnya. Misalnya membuat kompos.

\section{Pendampingan}

Pendampingan yang dimaksud dalam penelitian ini adalah dimana para penyuluh memberikan pendampingan secara langsung agar para ketua kelompok lebih mengetahui bagaimana melakukan pemupukan dengan baik dan benar, misalnya.

\section{HASIL PENELITIAN DAN PEMBAHASAN}

Dari hasil deskripsi penelitian sebagaimana diuraikan di atas tentang pembinaan kelompok tani oleh penyuluh pertanian Kecamatan Kwandang Kabupaten Gorontalo Utara, ditemukan sebagai berikut

Kelompok tani adalah kumpulan petani yang dibentuk atas dasar kesamaan kondisi lingkungan (sosial, ekonomi dan sumberdaya) kelompok tani juga dapat diartikan sebagai organisasi non formal di pedesaan. Umumnya kelompok tani dibentuk atas dasar kesamaan tujuan dan kesamaan kondisi dalam suatu lingkungan petani. Dengan dibentuknya kelompok tani mempermudah untuk menyampaikan materi penyuluhan berupa pembinaan dan pendampingan petani agar memiliki kemandirian bisa menerapkan inivasi dan mampu memperoleh pendapatan yang meningkat dan layak. 
PUBLIK: Jurnal Manajemen Sumber Daya Manusia, Administrasi dan Pelayanan Publik Sekolah Tinggi Ilmu Administrasi Bina Taruna Gorontalo Volume V Nomor 2 Desember 2018

\begin{tabular}{|c|c|}
\hline $\begin{array}{l}\text { Penyuluhan antara unit } \\
\text { penyuluh pertanian dengan } \\
\text { kelompok pertanian dalam hal } \\
\text { memberikan pembinaan pada } \\
\text { kelompok tani di Kecamatan } \\
\text { Kwandang Kabupaten Gorontalo } \\
\text { Utara harus dilakukan agar supaya } \\
\text { pembinaan berjalan dengan lancar, } \\
\text { namun berdasarkan hasil penelitian } \\
\text { ditemukan penyuluhan yang } \\
\text { dilakukan oleh penyuluh pertanian } \\
\text { kepada kelompok tani belum terjalin } \\
\text { dengan baik dimana sering terjadi } \\
\text { penyampain informasi yang tidak } \\
\text { sampai kepada seluruh anggota } \\
\text { kelompok tani tidak semua anggota } \\
\text { yang sempat mengikuti pertemuan } \\
\text { tersebut sehingga anggota banyak } \\
\text { yang tidak paham. } \\
\text { Dalam melakukan pembinaan } \\
\text { penyuluh pertanian melaksanakan } \\
\text { pelatihan. Pelatihan yang diberikan }\end{array}$ & 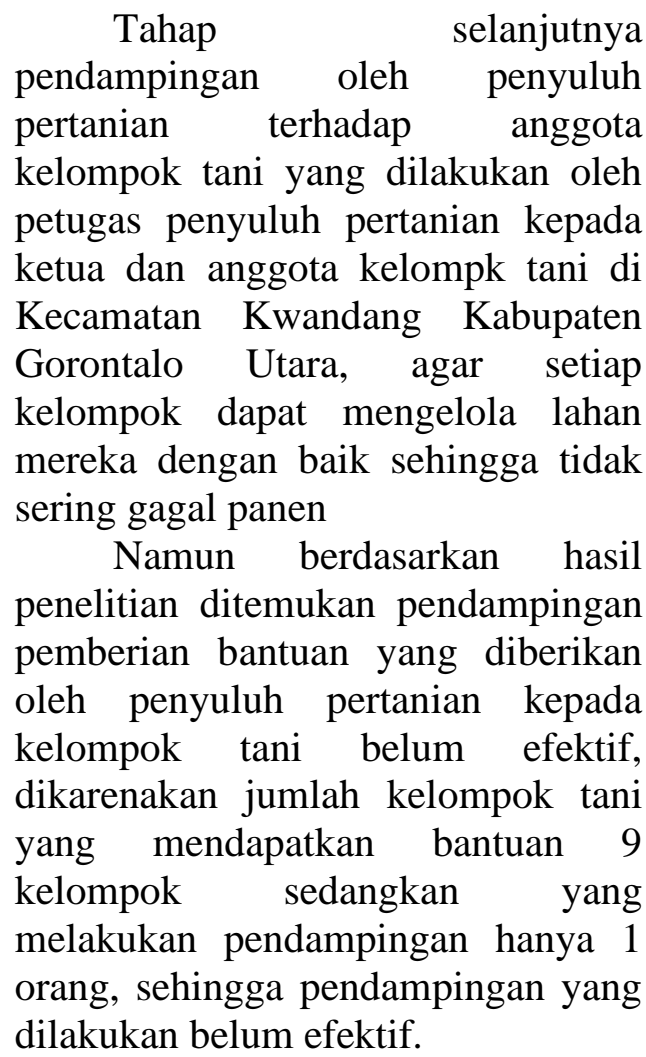 \\
\hline
\end{tabular}
oleh penyuluh pertanian kepada anggota kelompok tani di Kecamatan Kwandang Kabupaten Gorontalo Utara, agar anggota dapat mengetahui atau dapat menambah wawasan tentang pertanian yang lebih baik. Namun berdasarkan hasil penelitian ditemukan pelatihan yang diberikan oleh penyuluh pertanian belum efektif. dikarenakan tidak semua anggota kelompok tani mengikuti pembinaan cara mengelolah tanaman dengan cara memberikan pupuk dan obat-obatan sesuai takaran yang dijelaskan oleh penyuluh pertanian, karena sebagian kelompok tani tidak mendapatkan informasi dari pihak yang berwenang dan yang ikut hanya sebagian anggota kelompok saja sedangkan pelatihan hanya dilaksanakan 1 kali. Sehingga pelatihan yang di laksanakan oleh penyuluh pertanian belum efektif.

\section{SIMPULAN}

Berdasarkan hasil deskripsi penelitian yang telah diuraikan tersebut, maka dapat disimpulkan sebagai berikut:

1. Ditinjau dari segi penyuluhan yang dilakukan oleh penyuluh pertanian terhadap kelompok tani yang ada di Desa Bulalo Kecamatan Kwandang Kabupaten Gorontalo Utara belum efektif.

2. Ditinjau dari segi pelatihan terhadap ketua dan anggota kelompok tani yang ada di Kecamatan Kwandang Kabupaten Gorontalo Utara belum efektif karena masih ada anggota kelompok yang tidak hadir.

3. Ditinjau dari segi pendampingan yang dilakukan oleh penyuluh pertanian Kabupaten Gorontalo utara tentang bantuan terhadap 
PUBLIK: Jurnal Manajemen Sumber Daya Manusia, Administrasi dan Pelayanan Publik Sekolah Tinggi Ilmu Administrasi Bina Taruna Gorontalo Volume V Nomor 2 Desember 2018

kelompok tani belum efektif karena dari 9 kelompok hanya memiliki 6 pendamping penyuluhan.

4. secara keseluruhan maka dapat disimpulan bahwa dari segi penyuluhan, pelatihan, pendampingan, belum efektif atau belum berjalan dengan baik sehingga dibutuhkan kerja sama yang baik antar kelompok tani dan petugas penyuluh pertanian agar mendapatkan hasil yang efektif.

\section{SARAN}

Berdasarkan simpulkan tersebut, maka dapat disarankan halhal sebagai berikut:

1. Perlunya pihak penyuluh pertanian melakukan penyuluhan secara lebih intensif kepada para ketua kelompok agar dapat dipahami sehingga dapat diteriskan kepada par anggotanya.

2. Perlunya pihak penyuluh pertanian melakukan atau mengadakan pelatihan secara lebih intensif agar para ketua kelompok mampu meneruskan materi yang diperoleh kepada para anggota tani.

3. Perlunya pihak penyuluh pertanian lebih intensif melakukan pendampingan kepada para ketua kelompok dan para anggota tani. Juga perlu menambahkan jumlah penyuluh agar semua petani dapat tertangani secara sempurna.

\section{DAFTAR PUSTAKA}

Ali, Faried. 2008. Teori Dan Konsep Administrasi. Makasar PT Rajagrafindo Persada
Ardana. 2012. Manajemen Sumber Daya Manusia. Bandung: PT. Remaja Rosda Karya.

Armosudiro. 2008. Konsep Organisasi. Jakarta: PT Raja Grafindo Persada.

Bohlander, George and Snell, Scott. 2010. Principles of Hukman Resounce. Management, 15 th ed Mason. OH: Sout Westem Cengage Learning

Chaniago. 2008. Kamus Besar Bahasa Indonesia. Cetakan V. Bandung: Pustaka Setia

Fathoni, H. Abdurrahman. 2008. Organisasi dan Manajemen Sumber Daya Manusia. Cetakan Pertama. Jakarta: Rineka Cipta.

Fathoni, H. Abdurrahman. 2009. Organisasi \& Manajemen Sumber Daya Manusia. Cetakan Ke-1. Jakarta: Rineka Cipta.

Gie, The Liang. 2015. Administrasi Perkantoran Modern. Cetakan Ketujuh. Yogyakarta: Tiara Wacana.

Hasibuan. S.P Malayu. 2010. Manajemen Sumber Daya Manusia. Cetakan Ke-7. Jakarta: PT. Bumi Akasara.

Hasibuan, Malayu S.P. 2008. Manajemen Sumber Daya Manusia. Edisi Revisi. Jakarta: PT. Bumi Aksara.

Haryadi, Hendi. 2009. Administrasi Perkantoran Untuk Manajemen \& Staf. Cetakan Pertama. Jakarta: Visimedia

I Ardana, 2012. Manajemen Sumber Daya Manusia. Yogyakarta: Penerbit Graha Ilmu,

Indrawijaya, Ibrahim Adam. 2010. Teori Perilaku, dan Budaya 
PUBLIK: Jurnal Manajemen Sumber Daya Manusia, Administrasi dan Pelayanan Publik Sekolah Tinggi Ilmu Administrasi Bina Taruna Gorontalo Volume V Nomor 2 Desember 2018

Organisasi Cetakan Ke-1. Bandung: Refika Aditima.

Kasmir. 2014. Kewirausahaan. Edisi Revisi. Jakarta: PT. Raja Grafindo Persada

Marwansyah. 2009. Manajemen Sumber Daya Manusia. Bandung: Alfabeta.

Maleong. 2012. Metode Penelitian Kualitatif. Bandung: PT Rosdakarta

Merill. 2010. Pembinaan Organisasi. Jakarta: PT Rajagrafindo Persada

Nawawi, Handari. 2009. Manajemen Sumber Daya Manusia. Cetakan Ketiga. Yogyakarta: Gama Press.

Nawawi, Hadari. 2007. Metode Penelitian Bidang Sosial. Cet. Keduabelas. Yogyakarta: Gadjah Mada University Press

Noe, Hollenbeck, Gerhart \& Wright. 2008. Fundamentals of Human Resources Managemen. New York

Rivai, Veithzal. 2008 Manajemen Sumber Daya Manusia Untuk Perusahaan: dari Teori Ke Praktis. Edisi Pertama. Jakarta: Penerbit PT. Raja Grafindo Persada

Rivai. 2014. Pemimpin Dan Kepemimpinan Dalam Organisasi. Jakarta: PT Raja Grafinfo Persada

Robbins, S Dan Coulter, M. 2010. Manajemen. Edisi Ke Delapan. Jakarta: PT Indeks.

Robbins dan Judge. 2008. Perilaku Organisasi. Edisi Duabelas. Jakarta: Penerbit Salemba Empat.

Ruky H. Achamad S. 2008. SDM Berkualitas Mengubah Visi
Menjadi Realitas. Jakarta: PT Gramedia Pustaka Utama.

Snell, A Scott, Bohlander, George 2010. Principles of Humas Resource Managemen, Internatonal. Edisi ke-15. South Western

Sufyarman. 2008. Pembinaan Sumber Daya. Jakarta: PT Raja Grafindo Parsada.

Sedarmayanti. 2007. Manajemen Sumber Daya Manusia Reformasi Birokrasi dan Manajemen Pegawai Negeri Sipil. Bandung: Reflika Aditima.

Sudjana. 2010. Pembinaan Sumber Daya Aparatur. Edisi Keenam. Bandung: Penerbit Tarsito.

Snell. 2010. Manajemen Sumber Daya Manusia. Cetakan Ketiga. Yogyakarta: Gama Press.

Soetjipto Dkk. 2008. Pembinaan Sumber Daya. Jakarta: PT Raja Grafindo Parsada.

Sugiyono. 2009. Metode Penelitian Kuantitatif, Kualitatif dan $R \& D$. Bandung: Alfabeta.

Sugiyono. 2008. Metode Penelitian Kuantitatif dan Kualitatif. Bandung: Alfabeta.

Sulistiyani, Rosidah. 2009. Pengembangan Sumber Daya Manusia. Jakarta: PT. Rineka Cipta.

Sunyoto, A. 2013. Pengembangan Sumber Daya Manusia. Jakarta: PT. Rineka Cipta.

Sutrisno. 2009. Manajemen Keuangan Teori, Konsep dan Aplikasi Ekonisia. Yogyakarta

Sutrisno, Edy. 2010. Manajemen Sumber Daya Manusia. Jakarta: Kencana Prenada Media Group 
Suwatno, Doni. 2014. Manajemen

Sumber Daya Manusia.

Jakarta: PT. Rineka Cipta.

Wibowo. 2007. Manajemen Kinerja.

Jakarta: PT Raja Grafindo

Parsada.

Winardi, J. 2010. Organisasi

Pengorganisasian. Cetakan

Pertama. Jakarta: Raja

Grafindo Persada.

Winardi. 2011. Teori Organisasi dan

Pengorganisasian. Devisi

Buku Perguruan Tinggi.

Wursanto. 2010. Dasar-Dasar Ilmu

Organisasi. Yogyakarta:

Andi Offset. 